\title{
Good Corporate Governance, Ukuran Perusahaan, dan Sustainability Report dengan Kepemilikan Institusional Sebagai Pemoderasi
}

\author{
Ida Ayu Sintya Puspita Dewi ${ }^{1}$ \\ Fakultas Ekonomi dan Bisnis \\ Universitas Udayana, Indonesia
}

\author{
I Wayan Ramantha ${ }^{2}$ \\ Fakultas Ekonomi dan Bisnis \\ Universitas Udayana, Indonesia
}

\begin{abstract}
Surel : sintyapuspita43@gmail.com
ABSTRAK

Penelitian ini bertujuan untuk memperoleh bukti empiris mengenai pengaruh dewan direksi, komisaris independen, komite audit, serta ukuran perusahaan pada sustainability report dengan kepemilikan institusional sebagai variabel moderasi. Jumlah sampel yang digunakan sebanyak 117, dengan metode pengumpulan sampel menggunakan metode purposive sampling, sedangkan metode pengumpulan data yang digunakan dalam penelitian ini adalah dokumentasi. Teknik analisis data yang digunakan yaitu Moderated Regression Analysis (MRA). Hasil penelitian menunjukkan bahwa dewan direksi, komisaris independen, dan komite audit berpengaruh positif pada sustainability report, sedangkan ukuran perusahaan tidak berpengaruh pada sustainability report. Selain itu, kepemilikan institusional mampu memoderasi pengaruh dewan direksi, komisaris independen, dan ukuran perusahaan pada sustainability report. Sedangkan kepemilikan institusional tidak mampu memoderasi pengaruh komite audit pada sustainability report.
\end{abstract}

Kata Kunci: Good Corporate Governance; Sustainability Report.

\section{Good Corporate Governance and Company Size on the Sustainability Report with Institutional Ownership as Moderation}

\begin{abstract}
This study aims to obtain empirical evidence regarding the influence of the board of directors, independent commissioners, audit committee, and company size on the sustainability report with institutional ownership as a moderating variable. The number of samples used was 117 , with the sample collection method using purposive sampling method, while the data collection method used in this study was documentation. The data analysis technique used is Moderated Regression Analysis (MRA). The results showed that the board of directors, independent commissioners, and audit committee had a positive effect on the sustainability report, while company size had no effect on the sustainability report. In addition, institutional ownership is able to moderate the influence of the board of directors, independent commissioners, and company size on the sustainability report. Meanwhile, institutional ownership was not able to moderate the effect of the audit committee on the sustainability report.
\end{abstract}

Keywords: Good Corporate Governance; Sustainability Report.

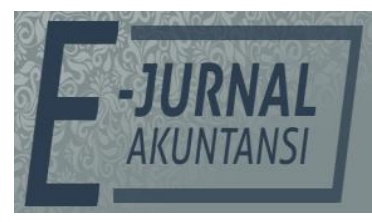

e-ISSN 2302-8556

Vol. 31 No. 6

Denpasar, Juni 2021

Hal. 1451-1466

10.24843/EJA.2021.v31.06.p08

PENGUTIPAN:

Dewi, I.A.S.P., \& Ramantha,

I W. (2021). Good Corporate

Governance, Ukuran

Perusahaan, dan

Sustainability Report dengan

Kepemilikan Institusional

Sebagai Pemoderasi. E-Jurnal

Akuntansi, 31(6), 1451-1466

RIWAYAT ARTIKEL:

Artikel Masuk: 5 Maret 2021

Artikel Diterima: 26 Mei 2021

Artikel dapat diakses : https://ojs.unud.ac.id/index.php/Akuntansi/index 


\section{PENDAHULUAN}

Tanggung jawab perusahaan akan menentukan keberlanjutan perusahaan tersebut karena adanya dampak dari aktivitas perusahaan (Lindawati \& Puspita, 2015). Dewasa ini, sering dijumpai perusahaan yang tidak bertanggungjawab sehingga menyebabkan kerusakan lingkungan, seperti yang terjadi di berbagai daerah dimana sumber daya alam yang dieksploitasi secara berlebihan tanpa memperhatikan dampak fisik dan sosialnya (Abdoellah, 2016). Hal inilah yang kemudian menjadi sorotan masyarakat agar perusahaan melaksanakan tanggungjawab sosial dan lingkungan akibat dari aktivitas perusahaan tersebut. Tujuan perusahaan kini tidak hanya mengejar keuntungan (profit) tetapi juga bertanggungjawab terhadap masyarakat (people) dan lingkungan (planet), yang dikenal dengan konsep 3P. Makna dari konsep ini yaitu agar kegiatan bisnis yang dilakukan tidak semata-mata mengejar keuntungan, namun dapat memenuhi kesejahteraan masyarakat, serta turut menjaga kelestarian lingkungan, melalui sustainability report (Fatchan \& Trisnawati, 2018).

Adanya sustainability report diharapkan dapat merubah cara pandang perusahaan untuk tidak berfokus pada keuntungan semata tanpa peduli terhadap lingkungan menjadi pandangan mengenai pembangunan keberlanjutan (Barung et al., 2018). Dalam membuktikan kepedulian terhadap masalah lingkungan dan sosial maka perusahaan harus menerbitkan laporan keberlanjutan. Hal ini akan membantu perusahaan dalam meningkatkan reputasi serta dapat menarik investor dan institusi (Glembotskaya et al. 2020). Di Indonesia masih belum banyak perusahaan yang menerbitkan sustainability report. Berbagai macam berita yang dapat diakses pada media massa ataupun media sosial menunjukkan bahwa masih banyak perusahaan di Indonesia yang belum menerapkan konsep 3P. Sofa \& Respati (2020) berpendapat bahwa dengan adanya berbagai fenomena yang terjadi, perusahaan diwajibkan untuk mempunyai komitmen sosial dan lingkungan, serta menerapkan bisnis yang berkelanjuan melalui Good Corporate Governance (GCG) yang berupaya memberi keuntungan kepada pemegang saham dan tetap memperhatikan keinginan pemangku kepentingan (stakeholder).

Teori stakeholder menyatakan bahwa perusahaan akan berupaya memenuhi kebutuhan stakeholder dengan cara mengungkapkan sustainability report (Madona \& Khafid, 2020). Adanya penerapan GCG diduga memiliki kemungkinan yang besar untuk melakukan pengungkapan tanggung jawab sosial lingkungan sebagai suatu upaya pemenuhan kebutuhan stakeholder sehingga dapat terjalin hubungan yang positif antara perusahaan dengan stakeholder. Penerapan GCG akan dilihat melalui mekanismenya yang diproksikan dengan dewan direksi, komisaris independen, komite audit, dan kepemilikan institusional. Dewan direksi sebagai pengelola perusahaan bertanggung jawab dalam penyusunan pedoman GCG perusahaan, menjamin kepatuhan perusahaan terhadap aturan serta regulasi yang berlaku (Sofa \& Respati, 2020).

Mahmood et al. (2018) menunjukan bahwa dewan direksi mempengaruhi sustainability report melalui jumlah rapat yang 
diselenggarakan dalam satu tahun maka diindikasikan semakin efektif komunikasi yang dilakukan untuk mengupayakan penerapan GCG dan luasnya keterbukaan informasi. Berbeda dengan pernyataan dalam penelitian Hasanuddin \& Suryani (2019) menyatakan bahwa dewan direksi memiliki fokus utama pada kegiatan bisnis dan operasi perusahaan sehingga tidak menjadikan pengungkapan informasi dalam pelaporan keberlanjutan menjadi prioritas. Selain itu, dewan direksi juga akan lebih fokus pada kinerja keuangan yang memiliki efek langsung daripada kinerja keberlanjutan yang memiliki efek jangka Panjang.

Pada struktur Corporate Governance di Indonesia terdapat beberapa komite dibawah Dewan Komisaris yang memiliki tugas dan fungsi sebagai pembantu utama Dewan Komisaris yaitu salah satunya komite audit. Keberadaan komite audit diharapkan lebih dapat mewujudkan akuntabilitas informasi dalam perusahaan termasuk mengenai keterbukaan informasi berupa sustainability report (Adila \& Syofyan, 2016). Hal ini diperkuat dengan pernyataan Aniktia \& Khafid (2015) dan Wang (2017) bahwa variabel independen komite audit berpengaruh terhadap sustainability report. Namun pada penelitian Madona \& Khafid (2020), Aliniar \& Wahyuni (2017), Barung et al. (2018) menyatakan hal yang berbeda yaitu komite audit tidak berpengaruh pada sustainability report diartikan bahwa sering atau tidaknya komite audit melakukan rapat pada perusahaan tidak selalu menjadi tolak ukur sustainability report suatu perusahaan.

Faktor lainnya yang dianalisis dapat mempengaruhi sustainability report yaitu kepemilikan institusional dan ukuran perusahaan. Tingkat kepemilikan institusional yang tinggi menimbulkan usaha pengawasan yang lebih besar oleh investor institusional sehingga dapat mengontrol manajer untuk tidak melakukan perbuatan yang tidak sejalan dengan kepentingan pemegang saham (Tamrin \& Maddatuang, 2019). Perusahaan yang memiliki kepemilikan institusional yang tinggi memerlukan pengungkapan informasi tentang tanggung jawab sosial perusahaan, yang akan menarik pemegang saham institusi baru karena perusahaan memiliki rencana kerja terkait dengan tanggung jawab sosial (Willyanto et al. 2019).

Hani (2017) berpendapat bahwa ukuran perusahaan sebagai salah satu karakteristik perusahaan yang turut menentukan tingkat kepercayaan investor, membutuhkan kredibilitas yang baik sehingga perusahaan perlu melakukan sumbangsih dalam pertumbuhan sosial dan lingkungan sekitar. Lucia \& Panggabean (2018) dalam penelitiannya menyatakan bahwa semakin besar perusahaan maka akan membawa pengeluaran yang lebih besar dalam mewujudkan legitimasi perusahaan, ini mungkin karena perusahaan cenderung untuk mengungkapkan informasi lebih luas termasuk sustainability report. Namun, Ruhana \& Hidayah (2020) menyatakan bahwa variabel ukuran perusahaan tidak berpengaruh terhadap tingkat sustainability report. Perusahaan kecil dapat mengungkapkan kegiatan tanggung jawab sosial perusahaannya sehingga dianggap mampu memberikan keuntungan baik secara langsung maupun tidak langsung dan mendapatkan legitimasi usaha dari seluruh stakeholder (Liana, 2019). 


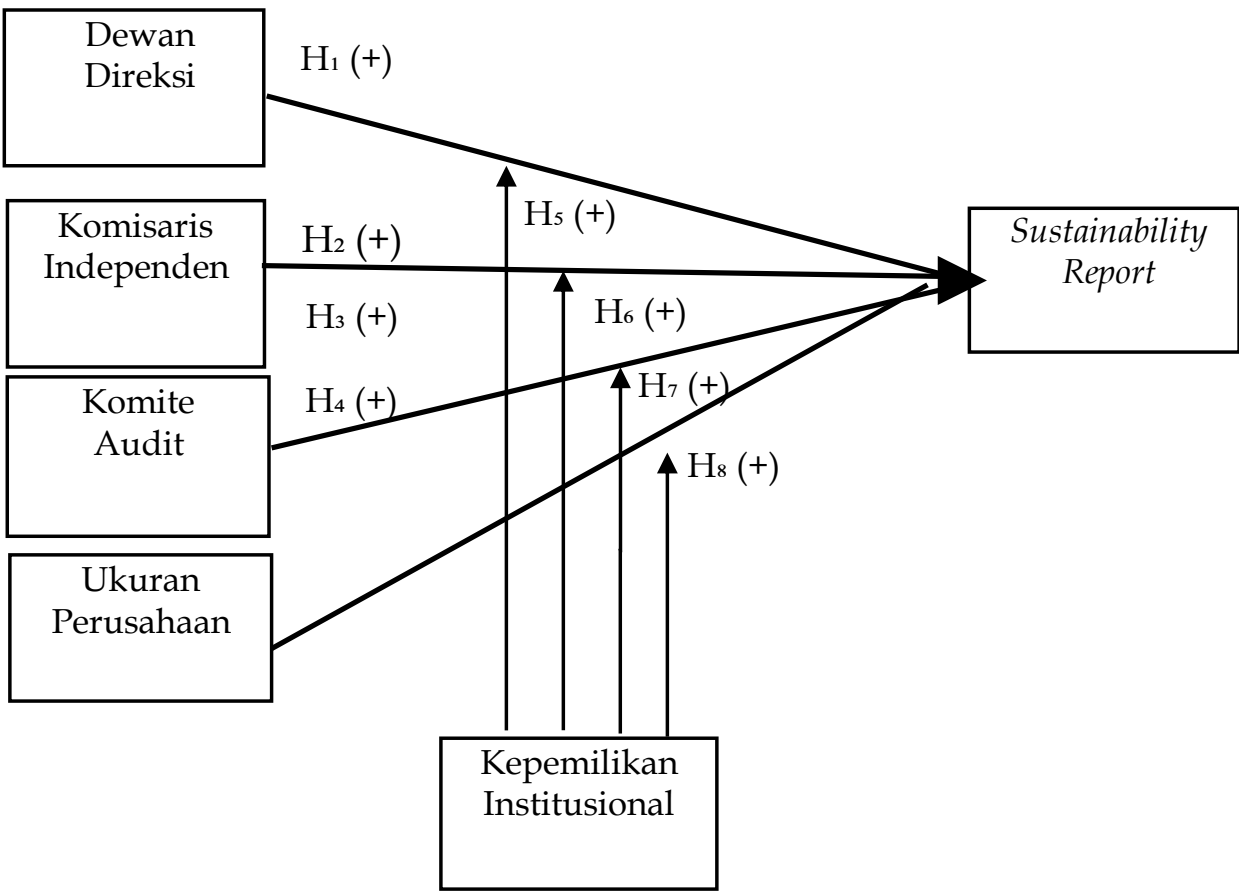

Sumber: Data Penelitian, 2021

Gambar 1. Kerangka Konseptual

Teori stakeholder menyatakan bahwa perusahaan harus dapat memenuhi harapan dan kepentingan pemangku kepentingan, termasuk dalam penyediaan informasi yaitu sustainability report (Madona \& Khafid, 2020). Semakin baik tata kelola perusahaan, semakin produktif tindakan manajer untuk meningkatkan kinerja perusahaan. Dalam penerapan tata kelola perusahaan yang baik terdapat prinsip transparansi (Zahir et al., 2020). Penelitian Sofa \& Respati (2020) dan Hani (2017) menyatakan bahwa dewan direksi memberikan pengaruh signifikan terhadap sustainability report. Berdasarkan uraian, maka hipotesis dalam penelitian ini dapat dirumuskan sebagai berikut.

$\mathrm{H}_{1}$ : Dewan direksi berpengaruh positif pada sustainability report.

Aliniar \& Wahyuni (2017) dan Diono et al. (2017) dalam penelitiannya menyatakan bahwa proporsi komisaris independen berpengaruh positif terhadap sustainability report. Menurut teori stakeholder, perusahaan dalam beroperasi juga harus memberikan manfaat kepada stakeholder nya. Semakin besar proporsi dewan komisaris independen diindikasikan semakin kritis dan berdaya guna pengendalian yang dilaksanakan direksi (Adila \& Syofyan, 2016). Berdasarkan uraian, maka hipotesis dalam penelitian ini dapat dirumuskan sebagai berikut.

$\mathrm{H}_{2}$ : Komisaris independen berpengaruh positif pada sustainability report.

Teori stakeholder menyatakan bahwa organisasi akan memilih secara sukarela mengungkapkan informasi tentang kinerja lingkungan, sosial dan intelektual mereka, melebihi dan lebih dari permintaan wajibnya, untuk memenuhi ekspektasi sesungguhnya atau yang diharapkan oleh stakeholder (Fatchan \& Trisnawati, 2018). Penelitian Aniktia \& Khafid (2015) dan Wang 
(2017) menyatakan bahwa ukuran komite audit berpengaruh positif terhadap sustainability report. Berdasarkan uraian, maka hipotesis dalam penelitian ini dapat dirumuskan sebagai berikut.

$\mathrm{H}_{3}$ : Komite audit berpengaruh positif pada sustainability report.

Berdasarkan teori legitimasi, perusahaan besar aktivitasnya akan lebih terlihat dibandingkan dengan perusahaan kecil sehingga tuntutan dan tekanan dari masyarakat akan lebih besar (Adila \& Syofyan, 2016). Penelitian Khafid (2015), Barung et al., (2018), Sofa \& Respati (2020), Zahir et al., (2020) menyatakan bahwa ukuran perusahaan berpengaruh pada sustainability report. Teori ini juga menyatakan bahwa ekspektasi pemegang saham dan kemampuan untuk memenuhi tuntutannya sangat penting dalam menjaga legitimasi perusahaan dan mencapai kinerja yang berkelanjutan (Ferri et al., 2016). Berdasarkan uraian, maka hipotesis dalam penelitian ini dapat dirumuskan sebagai berikut: $\mathrm{H}_{4}$ : Ukuran perusahaan berpengaruh positif pada sustainability report.

Menurut teori stakeholder, perusahaan dapat memelihara hubungan yang kuat dengan pemangku kepentingan dengan mencapai tujuan mereka. Hubungan ini juga dapat meningkatkan reputasi perusahaan dan berdampak positif terhadap kinerja perusahaan (Bose et al., 2017). Apalagi menanggapi tuntutan pemangku kepentingan mengarah pada keunggulan kompetitif dan keberlanjutan (Needles et al., 2016). Penelitian Aliniar \& Wahyuni (2017) menyatakan bahwa kepemilikan institusional berpengaruh pada sustainability report, dikarenakan kepemilikan institusional memiliki hak untuk mengendalikan pihak manajemen melalui proses monitoring secara efektif sehingga dapat mendorong kinerja manajemen untuk mengutamakan kepentingan pihak lain (stakeholder), sehingga dengan kepemilikan saham institusional yang besar dapat mendorong kualitas informasi dan sustainability report yang dilakukan oleh perusahaan. Berdasarkan uraian, maka hipotesis dalam penelitian ini dapat dirumuskan sebagai berikut.

$\mathrm{H}_{5}$ : Kepemilikan institusional memoderasi pengaruh positif dewan direksi pada sustainability report.

Premis dasar dari teori stakeholder adalah bahwa semakin kuat hubungan korporasi, maka akan semakin baik bisnis korporasi. Sebaliknya, semakin buruk hubungan korporasi maka akan semakin sulit. Hubungan yang kuat dengan para pemangku kepentingan adalah berdasarkan kepercayaan, rasa hormat, dan kerjasama (Pramiana \& Anisah, 2018). Salah satu tugas utama dewan komisaris independen adalah memantau proses keterbukaan dan efektivitas komunikasi dalam perusahaan untuk menyediakan tersedianya informasi yang tepat waktu dan jelas kepada stakeholder (Awalia et al., 2015). Sejalan dengan penelitian yang dilakukan oleh Aliniar \& Wahyuni (2017) dan Zahir et al., (2020) menyatakan bahwa kepemilikan saham institusional berpengaruh positif pada sustainability report. Berdasarkan uraian, maka hipotesis dalam penelitian ini dapat dirumuskan sebagai berikut.

$\mathrm{H}_{6}$ : Kepemilikan institusional memoderasi pengaruh positif komisaris independen pada sustainability report.

Sesuai dengan teori stakeholder, semakin banyak dan kuat posisi stakeholder, semakin besar kecenderungan perusahaan untuk mengadaptasi diri terhadap keinginan para stakeholder. Perusahaan dengan kepemilikan institusional yang 
besar (lebih dari 5\%) mengindikasikan kemampuannya untuk memonitor manajemen, yang memberikan pemahaman bahwa dengan tingkat kepemilikan institusional yang semakin tinggi akan meningkatkan tingkat pengawasan terhadap manajemen (Noviani et al., 2017). Mengacu pada teori stakeholder, perusahaan ingin memenuhi harapan para pemangku kepentingan, salah satunya dengan membuat sustainability report yang menggambarkan tentang kegiatan perusahaan di bidang ekonomi, sosial dan lingkungan yang dibutuhkan oleh pemangku kepentingan sehingga mendapatkan legitimasi dari masyarakat. Berdasarkan uraian, maka hipotesis dalam penelitian ini dapat dirumuskan sebagai berikut.

$\mathrm{H}_{7}$ : Kepemilikan institusional memoderasi pengaruh positif komite audit pada sustainability report.

Teori stakeholder menjelaskan bahwa tiap pemangku kepentingan turut menentukan kinerja perusahaan, termasuk kinerja sosialnya. Institusi dianggap sebagai pihak yang paling mampu dalam mengawasi dan mengelola investasinya, baik dari segi pengetahuan, sistem informasi, maupun sumber daya yang dimiliki (Dharmawan Krisna \& Suhardianto, 2016). Pemegang saham institusional juga memiliki opportunity, resources, dan expertise untuk menganalisis kinerja dan tindakan manajemen (Wartyana \& Apriweni, 2018). Berdasarkan teori legitimasi, perusahaan besar aktivitasnya akan lebih terlihat dibandingkan dengan perusahaan kecil sehingga tuntutan dan tekanan dari masyarakat akan lebih besar (Adila \& Syofyan, 2016). Berdasarkan uraian, maka hipotesis dalam penelitian ini dapat dirumuskan sebagai berikut.

$\mathrm{H}_{8}$ : Kepemilikan institusional memoderasi pengaruh positif ukuran perusahaan pada sustainability report.

\section{METODE PENELITIAN}

Desain penelitian ini menggunakan pendekatan kuantitatif berbentuk asosiatif. Penelitian ini dilakukan pada perusahaan-perusahaan yang terdaftar di Bursa Efek Indonesia (BEI) dengan mengakses data melalui situs resmi BEI dan situs resmi perusahaan. Obyek penelitian ini adalah sustainability report pada perusahaan-perusahaan yang terdaftar di Bursa Efek Indonesia (BEI). Adapun variabel independen dalam penelitian ini yaitu dewan direksi $\left(X_{1}\right)$, komisaris independen $\left(X_{2}\right)$, komite audit $\left(X_{3}\right)$, dan ukuran perusahaan $\left(X_{4}\right)$, dengan variabel moderasi yaitu kepemilikan institusional (M), serta variabel dependen yaitu sustainability report $(\mathrm{Y})$. Sumber data yang digunakan adalah data sekunder yaitu laporan tahunan (annual report) serta sustainability report untuk mengetahui informasi mengenai variabel dependen pada perusahaan-perusahaan yang terdaftar di Bursa Efek Indonesia (BEI). Populasi dalam penelitian ini yaitu seluruh perusahaan yang terdaftar di Bursa Efek Indonesia yang berjumah 713 perusahaan. Penentuan sampel penelitian ini menggunakan metode purposive sampling. Metode pengumpulan data penelitian ini menggunakan teknik dokumentasi. Teknik analisis data yang digunakan dalam penelitian ini adalah Moderated Regression Analysis (MRA). Analisis ini dilakukan untuk mengetahui pengaruh variabel moderasi dalam memperkuat atau memperlemah hubungan antara variabel independen dan variabel dependen. Persamaan regresi yang dapat dirumuskan sebagai berikut 
$Y=\alpha+\beta_{1} X_{1}+\beta_{2} X_{2}+\beta_{3} X_{3}+\beta_{4} X_{4}+\beta_{5} X_{1} \cdot M+\beta_{6} X_{2} \cdot M+\beta_{5} X_{3} \cdot M+\beta_{5} X_{4} \cdot M+\varepsilon \ldots(1)$

Keterangan:

$\mathrm{Y}=$ Sustainability report

$\mathrm{a} \quad=$ Konstanta

$\beta=$ Koefisien regresi

$X_{1} \quad=$ Dewan direksi

$\mathrm{X}_{2} \quad=$ Komisaris independen

$\mathrm{X}_{3} \quad=$ Komite audit

$\mathrm{X}_{4} \quad=$ Ukuran perusahaan

$\mathrm{M} \quad=$ Kepemilikan institusional

$\mathrm{X}_{1} . \mathrm{M}=$ Interaksi antara dewan direksi dengan kepemilikan institusional

$\mathrm{X}_{2} \cdot \mathrm{M}=$ Interaksi antara komisaris independen dengan kepemilikan institusional

$\mathrm{X}_{3} . \mathrm{M}=$ Interaksi antara komite audit dengan kepemilikan institusional

$\mathrm{X}_{4} \mathrm{M}=$ Interaksi antara ukuran perusahaan dengan kepemilikan institusional

$\varepsilon \quad=$ Error

\section{HASIL DAN PEMBAHASAN}

Statistik deskriptif dapat digunakan bila peneliti hanya ingin mendeskripsikan data sampel, dan tidak ingin membuat kesimpulan yang berlaku untuk populasi dimana sampel diambil (Sugiyono, 2019: 207). Hasil statistik deskriptif yang disajikan dalam Tabel 1. dapat dideskripsikan sebagai berikut.

Tabel 1. Hasil Analisis Statistik Deskriptif

\begin{tabular}{llllll}
\hline Variabel & N & Minimum & Maksimum & $\begin{array}{l}\text { Rata- } \\
\text { rata }\end{array}$ & $\begin{array}{l}\text { Deviasi } \\
\text { Standar }\end{array}$ \\
\hline Dewan direksi & 117 & 4 & 96 & 39,64 & 18,134 \\
Komisaris independen & 117 & 0,20 & 0,80 & 0,411 & 0,102 \\
Komite audit & 117 & 3 & 77 & 12,56 & 13,096 \\
Ukuran perusahaan & 117 & 28,72 & 34,45 & 30,95 & 1,287 \\
Kepemilikan institusional & 117 & 0,07 & 0,98 & 0,648 & 1,945 \\
Sustainability report & 117 & 0,06 & 1,00 & 0,305 & 0,148 \\
\hline
\end{tabular}

Sumber: Data Penelitian, 2021

Variabel dewan direksi yang berjumlah 117 sampel memiliki nilai terkecil sebesar 4 dengan nilai rata-rata variabel dewan direksi sebesar 39,64 menunjukkan rata-rata dewan direksi dalam perusahaan sampel sebanyak 39,64\%, dan deviasi standar variabel sebesar 18,134. Variabel komisaris independen yang berjumlah 117 sampel memiliki nilai terkecil sebesar 0,20 dengan nilai rata-rata variabel komisaris independen sebesar 0,41 menunjukkan rata-rata komisaris independen dalam perusahaan sampel sebanyak $41 \%$, dan nilai deviasi standar sebesar 0,102. Variabel komite audit yang berjumlah 117 sampel memiliki nilai terkecil sebesar 3 dengan nilai rata-rata variabel komite audit sebesar 12,56 dan nilai deviasi standar sebesar 13,096. Variabel ukuran perusahaan yang berjumlah 117 sampel memiliki nilai terkecil sebesar 28,72 dengan nilai rata-rata variabel ukuran perusahaan sebesar 30,95 dan nilai deviasi standar sebesar 1,287. Variabel kepemilikan institusional yang berjumlah 117 sampel memiliki nilai terkecil sebesar 0,07 dengan rata-rata variabel kepemilikan 
institusional sebesar 0,648 dan nilai deviasi standar sebesar 1,945. Variabel sustainability report yang berjumlah 117 sampel memiliki nilai terkecil sebesar 0,06 dengan nilai rata-rata variabel sustainability report sebesar 0,305 dan nilai deviasi standar sebesar 0,148.

\section{Tabel 2. Hasil Uji Normalitas}

\begin{tabular}{lr}
\hline \multicolumn{1}{c}{ Unstandardized Residual } \\
\hline $\mathrm{N}$ & 117 \\
Kolmogorov-Smirnov Z & 0,093 \\
Asymp. Sig. (2-tailed) & 0,065 \\
\hline
\end{tabular}

Sumber: Data Penelitian, 2021

Berdasarkan hasil analisis didapat nilai signifikansi sebesar 0,065 yang lebih besar dari 0,05. Oleh karena nilai signifikansi uji Kolmogorov-Smirnov lebih dari 0,05 maka dapat disimpulkan bahwa data yang diuji berdistribusi normal. Hasil uji multikolinearitas dapat dilihat pada Tabel 4.4 sebagai berikut.

\section{Tabel 3. Hasil Uji Multikolinearitas}

\begin{tabular}{llc}
\hline \multirow{2}{*}{ Variabel } & \multicolumn{2}{c}{ Statistik Multikolinearitas } \\
\cline { 2 - 3 } & Tolerance & VIF \\
\hline Dewan direksi $\left(\mathrm{X}_{1}\right)$ & 0,869 & 1,151 \\
Komisaris independen $\left(\mathrm{X}_{2}\right)$ & 0,902 & 1,109 \\
Komite audit $\left(\mathrm{X}_{3}\right)$ & 0,851 & 1,175 \\
Ukuran perusahaan $\left(\mathrm{X}_{4}\right)$ & 0,953 & 1,050 \\
Kepemilikan institusional $(\mathrm{M})$ & 0,862 & 1,160 \\
\hline
\end{tabular}

Sumber: Data Penelitian, 2021

Hasil uji multikolinearitas menunjukkan bahwa variabel yang digunakan dalam penelitian memiliki nilai tolerance lebih besar dari 0,10 dan nilai VIF lebih kecil dari 10 sehingga dapat dinyatakan bahwa kelima variabel pada model regresi yang ada, tidak terjadi gejala multikolinearitas. Hasil uji heterokedastisitas untuk seluruh sampel disajikan dalam Tabel 4. sebagai berikut.

\section{Tabel 4. Hasil Uji Heterokedastisitas}

\begin{tabular}{lc}
\hline Variabel & Sig. \\
\hline Dewan direksi $\left(\mathrm{X}_{1}\right)$ & 0,430 \\
Komisaris independen $\left(\mathrm{X}_{2}\right)$ & 0,533 \\
Komite audit $\left(\mathrm{X}_{3}\right)$ & 0,233 \\
Ukuran perusahaan $\left(\mathrm{X}_{4}\right)$ & 0,079 \\
Kepemilikan institusional & 0,901
\end{tabular}

Sumber: Data Penelitian, 2021

Hasil uji heterokedastisitas menunjukkan nilai nilai signifikansi masingmasing variabel seluruhnya lebih besar dari 0,05. Dapat disimpulkan bahwa variabel pada model regresi yang ada, tidak terjadi gejala heteroskedastisitas. Hasil uji autokorelasi disajikan pada Tabel 5.

Tabel 5. Hasil Uji Autokorelasi

\begin{tabular}{llll}
\hline Model & $\mathrm{R}$ & $\mathrm{R}^{2}$ & Durbin-Watson \\
\hline 1 & 0,428 & 0,147 & 1,913 \\
\hline
\end{tabular}

Sumber: Data Penelitian, 2021 
Berdasarkan Tabel 5. menunjukkan bahwa nilai Durbin Watson sebesar 1,913. Nilai du untuk jumlah sampel (N) sebanyak 117 dengan jumlah variabel sebanyak 5 adalah sebesar 1,7696 maka nilai 4 -du yang didapat adalah 2,2304. Hasil uji autokorelasi adalah du $<\mathrm{dw}$, 4-du yaitu 1,7696 <1,913 <2,2304, maka dengan demikian tidak terjadi autokorelasi.

Penelitian ini menggunakan Moderated Regression Analysis (MRA). Hasil analisis dapat dilihat pada Tabel 6 .

Tabel 6. Hasil Uji Moderated Regression Analysis

\begin{tabular}{|c|c|c|c|c|c|c|}
\hline \multirow{2}{*}{\multicolumn{2}{|c|}{ Model }} & \multicolumn{2}{|c|}{$\begin{array}{l}\text { Unstandardized } \\
\text { Coefficients }\end{array}$} & \multirow{2}{*}{$\begin{array}{l}\text { Standardizert } \\
\text { Coefficient } \\
\text { Beta }\end{array}$} & \multirow[t]{2}{*}{$t$} & \multirow[t]{2}{*}{ Sig } \\
\hline & & $B$ & Std.Erorr & & & \\
\hline \multirow[t]{12}{*}{1} & (Constant) & 0,716 & 0,315 & & 2,276 & 0,025 \\
\hline & $X_{1}$ & 0,021 & 0,014 & 0,060 & 0,633 & 0,028 \\
\hline & $X_{2}$ & 1,310 & 0,523 & 0,903 & 2,506 & 0,014 \\
\hline & $X_{3}$ & 0,024 & 0,010 & 0,450 & 4,565 & 0,000 \\
\hline & $X_{4}$ & 0,017 & 0,011 & 0,002 & 0,017 & 0,986 \\
\hline & $\mathrm{X}_{1 . M}$ & 3,054 & 0,000 & 0,012 & 0,141 & 0,036 \\
\hline & $\mathrm{X}_{2 .} \mathrm{M}$ & 1,337 & 0,698 & 1,098 & 1,915 & 0,028 \\
\hline & $\mathrm{X}_{3} \cdot \mathrm{M}$ & 3,628 & 0,006 & 0,009 & 0,101 & 0,920 \\
\hline & $\mathrm{X}_{4 . \mathrm{M}}$ & 0,014 & 0,009 & 0,567 & 1,505 & 0,031 \\
\hline & Adjusted $\mathrm{R}^{2}$ & & & & & 0,151 \\
\hline & F Hitung & & & & & 3,576 \\
\hline & Sig F & & & & & 0,001 \\
\hline
\end{tabular}

Sumber: Data Penelitian, 2021

Berdasarkan Tabel 6. maka dapat diperoleh persamaan Moderated Regression Analysis (MRA) sebagai berikut.

$$
\begin{gathered}
\mathrm{Y}=0,716+0,021 \mathrm{X}_{1}+1,310 \mathrm{X}_{2}+0,024 \mathrm{X}_{3}+0,017 \mathrm{X}_{4}+3,054 \mathrm{X}_{1} \cdot \mathrm{M}+1,337 \mathrm{X}_{2} \cdot \mathrm{M}+ \\
3,628 \mathrm{X}_{3} \cdot \mathrm{M}+0,014 \mathrm{X}_{4} \cdot \mathrm{M}
\end{gathered}
$$

Nilai koefisien variabel dewan direksi $\left(X_{1}\right)$ bernilai positif sebesar 0,021 artinya apabila nilai dewan direksi $\left(\mathrm{X}_{1}\right)$ naik satu satuan maka sustainability report (Y) akan meningkat sebesar 0,021 dengan asumsi variabel lainnya konstan. Nilai koefisien variabel komisaris independen $\left(X_{2}\right)$ bernilai positif sebesar 1,310 artinya apabila nilai komisaris independen $\left(\mathrm{X}_{2}\right)$ naik satu satuan maka sustainability report (Y) akan meningkat sebesar 1,310 dengan asumsi variabel lainnya konstan. Nilai koefisien variabel komite audit $\left(X_{3}\right)$ bernilai positif sebesar 0,024 artinya apabila nilai komite audit $\left(\mathrm{X}_{3}\right)$ naik satu satuan maka sustainability report $(\mathrm{Y})$ akan meningkat sebesar 0,024 dengan asumsi variabel lainnya konstan. Nilai koefisien variabel ukuran perusahaan $\left(\mathrm{X}_{4}\right)$ bernilai positif sebesar 0,017 artinya apabila nilai ukuran perusahaan $\left(\mathrm{X}_{4}\right)$ naik satu satuan maka sustainability report $(\mathrm{Y})$ akan meningkat sebesar 0,017 dengan asumsi variabel lainnya konstan.

Nilai koefisien variabel pemoderasi dengan model interaksi $\left(X_{1} M\right)$ bernilai positif sebesar 3,054 dapat disimpulkan bahwa apabila nilai interaksi dewan direksi dengan kepemilikan institusional $\left(X_{1} . M\right)$ bertambah satu satuan, maka nilai dari sustainability report $(\mathrm{Y})$ akan meningkat sebesar 3,054 satuan dengan asumsi variabel lainnya konstan. Nilai koefisien variabel pemoderasi dengan model interaksi $\left(\mathrm{X}_{2} \cdot \mathrm{M}\right)$ bernilai positif sebesar 1,337 dapat disimpulkan bahwa apabila nilai interaksi komisaris independen dengan kepemilikan institusional $\left(\mathrm{X}_{2} . \mathrm{M}\right)$ bertambah satu satuan, maka nilai dari sustainability report $(\mathrm{Y})$ akan 
meningkat sebesar 1,337 satuan dengan asumsi variabel lainnya konstan. Nilai koefisien variabel pemoderasi dengan model interaksi $\left(X_{3} \cdot M\right)$ bernilai positif sebesar 3,628 dapat disimpulkan bahwa apabila nilai interaksi komite audit dengan kepemilikan institusional $\left(X_{3} . \mathrm{M}\right)$ bertambah satu satuan, maka nilai dari sustainability report $(\mathrm{Y})$ akan meningkat sebesar 3,628 satuan dengan asumsi variabel lainnya konstan. Nilai koefisien variabel pemoderasi dengan model interaksi $\left(\mathrm{X}_{4} \mathrm{M}\right)$ bernilai positif sebesar 0,014 dapat disimpulkan bahwa apabila nilai interaksi ukuran perusahaan dengan kepemilikan institusional $\left(\mathrm{X}_{4} \cdot \mathrm{M}\right)$ bertambah satu satuan, maka nilai dari sustainability report (Y) akan meningkat sebesar 0,014 satuan dengan asumsi variabel lainnya konstan.

Hasil uji kelayakan model (Uji F) diperoleh nilai $F$ hitung sebesar 3,576 dengan signifikansi sebesar 0,001. Nilai ini lebih kecil dari 0,05 sehingga dapat disimpulkan bahwa model Moderated Regression Analysis (MRA) layak digunakan. Nilai Adjusted $\mathrm{R}^{2}$ sebesar 0,151 memiliki arti bahwa variasi sustainability report dapat dijelaskan sebesar $15,1 \%$ oleh variabel dewan direksi, komisaris independen, komite audit, ukuran perusahaan dan interaksi kepemilikan institusional dengan variabel independen sedangkan sisanya 84,9\% dipengaruhi oleh variabel lain yang tidak dijelaskan dalam penelitian ini.

Hipotesis pertama menyatakan bahwa dewan direksi berpengaruh positif pada sustainability report. Hasil pengujian hipotesis menunjukkan koefisien regresi dewan direksi sebesar 0,633 dengan tingkat signifikansi yang diperoleh sebesar 0,028 lebih kecil dari $\mathrm{a}=0,05$, sehingga dapat disimpulkan bahwa hipotesis diterima. Berdasarkan Code of Corporate Governance yang dikeluarkan oleh Komite Nasional Kebijakan Governance (2006) menyatakan fungsi pengelolaan perusahaan yang dilakukan dewan direksi salah satunya adalah tanggung jawab sosial. Hasil penelitian ini berhasil membuktikan berlakunya teori stakeholder sebagai teori yang mendasari penelitian ini. Hasil penelitian ini sejalan dengan penelitian yang dilakukan oleh Sofa \& Respati (2020) dan Sinaga (2017) yang mendapatkan hasil bahwa dewan direksi berpengaruh positif pada sustainability report. Sinaga (2017) menyatakan dalam penelitiannya, jika tata kelola perusahaan di perusahaan sudah berjalan dengan baik, tercermin dari seringnya komunikasi dalam rapat dewan, semakin besar perusahaan dalam mengekspresikan kinerjanya, salah satunya sustainability report.

Hipotesis kedua menyatakan bahwa komisaris independen berpengaruh positif pada sustainability report. Hasil pengujian hipotesis menunjukkan koefisien regresi komisaris independen sebesar 2,506 dengan tingkat signifikansi yang diperoleh sebesar 0,014 lebih kecil dari $a=0,05$ sehingga dapat disimpulkan bahwa hipotesis diterima. Semakin besar proporsi dewan komisaris independen diindikasikan semakin kritis dan berdaya guna pengendalian yang dilaksanakan direksi, kemudian hal ini akan meningkatkan tuntutan mengenai sustainability report (Adila \& Syofyan, 2016). Hasil penelitian ini sejalan dengan penelitian yang dilakukan oleh Aliniar \& Wahyuni (2017), Diono et al. (2017), Burns Weston (2015) yang mendapatkan hasil bahwa komisaris independen berpengaruh positif pada sustainability report.

Hipotesis ketiga menyatakan bahwa komite audit berpengaruh positif pada sustainability report. Hasil pengujian menunjukan koefisien regresi komite audit sebesar 4,565 dengan tingkat signifikansi yang diperoleh sebesar 0,000 lebih kecil 
dari $\mathrm{a}=0,05$ sehingga dapat disimpulkan bahwa hipotesis diterima. Seringnya penyelenggaraan rapat komite audit akan meningkatkan efektivitas pengendalian internal dan pengawasan terhadap dewan direksi dalam menerapkan GCG termasuk mengenai keterbukaan informasi berupa sustainability report. Hasil penelitian ini sejalan dengan penelitian yang dilakukan oleh Dharmawan Krisna \& Suhardianto (2016), Aniktia \& Khafid (2015), dan Ruhana \& Hidayah (2020) yang mendapatkan hasil bahwa komite audit berpengaruh positif pada sustainability report.

Hipotesis keempat menyatakan bahwa ukuran perusahaan berpengaruh pada sustainability report. Hasil pengujian menunjukan koefisien regresi ukuran perusahaan sebesar 0,017 dengan tingkat signifikansi yang diperoleh sebesar 0,986 lebih besar dari a=0,05 sehingga dapat disimpulkan bahwa hipotesis ditolak. Untuk mendapatkan legitimasi dari pemangku kepentingan, perusahaan besar tidak akan selalu mengungkapkan tanggung jawab ekonomi, lingkungan, dan sosial dalam laporan keberlanjutan untuk memiliki pengaruh pada pihak internal dan eksternal yang memiliki kepentingan dalam perusahaan (Ruhana dan Hidayah, 2020). Hasil penelitian ini sejalan dengan penelitian yang dilakukan oleh Aliniar \& Wahyuni (2017), Adila \& Syofyan (2016), Madona \& Khafid (2020), Diono et al. (2017), Liana (2019) yang mendapatkan hasil bahwa ukuran perusahaan tidak berpengaruh pada sustainability report. Hal ini juga didukung dengan penelitian yang dilakukan oleh Adila \& Syofyan (2016) yang menyatakan bahwa ukuran perusahaan tidak menjadi landasan perusahaan untuk mengungkapkan informasi, besar atau kecilnya perusahaan sudah menjadi kewajiban bagi perusahaan untuk mengungkapkan informasi lingkungan dan sosialnya.

Hipotesis kelima menyatakan bahwa kepemilikan institusional memoderasi pengaruh dewan direksi pada sustainability report. Hasil pengujian menunjukan nilai koefisien variabel moderasi yaitu interaksi antara kepemilikan institusional dengan dewan direksi sebesar 0,141 dengan tingkat signifikansi yang diperoleh sebesar 0,036 lebih kecil dari $a=0,05$ sehingga dapat disimpulkan bahwa hipotesis dterima. Semakin besar presentase saham yang dimiliki oleh pihak institusi menyebabkan pengawasan yang dilakukan lebih efektif. Investor institusional memiliki power dan experience untuk bertanggung jawab dalam menerapkan prinsip Corporate Governance untuk melindungi hak dan kepentingan seluruh pemegang saham, sehingga mereka menuntut perusahaan untuk melakukan komunikasi secara transparan (Barung et al., 2018). Hasil penelitian ini sejalan dengan penelitian yang dilakukan oleh Nurleni et al. (2017), Rohmah (2015), Aliniar \& Wahyuni (2017), Majeed et al. (2015) yang mendapatkan hasil bahwa kepemilikan institusional berpengaruh positif pada sustainability report.

Hipotesis keenam menyatakan bahwa kepemilikan institusional mampu memoderasi pengaruh komisaris independen pada sustainability report. Hasil pengujian menunjukan nilai koefisien variabel moderasi yaitu interaksi antara kepemilikan institusional dengan komisaris independen sebesar 1,915 dengan tingkat signifikansi yang diperoleh sebesar 0,028 lebih kecil dari $\mathrm{a}=0,05$ sehingga dapat disimpukan bahwa hipotesis diterima. Menurut Manurung (2017) omisaris independen berperan penting dalam meningkatkan citra perusahaan dan 
bertindak untuk memantau dan memastikan bahwa perusahaan dikelola dengan baik oleh manajemen. Adanya kepemilikan saham yang tinggi oleh pihak institusi tersebut membuat komisaris independen dapat memberikan power kepada Dewan Komisaris untuk menekan manajemen dalam meningkatkan kualitas pengungkapan perusahaan salah satunya pengungkapan tanggung jawab sosial melalui sustainability report. Hasil penelitian ini sejalan dengan penelitian yang dilakukan oleh Nurleni et al. (2017), Rohmah (2015), Aliniar \& Wahyuni (2017), Majeed et al. (2015) yang mendapatkan hasil bahwa kepemilikan institusional berpengaruh positif pada sustainability report.

Hipotesis ketujuh menyatakan bahwa kepemilikan institusional memoderasi pengaruh komite audit pada sustainability report. Hasil pengujian menunjukan nilai koefisien variabel moderasi yaitu interaksi antara kepemilikan institusional dengan komite audit sebesar 0,101 dengan tingkat signifikansi yang diperoleh sebesar 0,920 lebih besar dari $a=0,05$ sehingga dapat disimpulkan bahwa hipotesis ditolak. Menurut Aliniar \& Wahyuni (2017) banyak komite audit yang hanya sekedar melakukan tugas-tugas rutin, dan tidak menganalisis secara mendalam kondisi pengendalian dan pelaksanaan tanggung jawab oleh manajemen. Hasil penelitian ini sejalan dengan penelitian yang dilakukan oleh Barung et al. (2018), Willyanto et al. (2019), Dharmawan Krisna \& Suhardianto (2016) yang mendapatkan hasil bahwa kepemilikan institusional tidak berpengaruh pada sustainability report. Hasil penelitian ini memberikan bukti empiris bahwa tingginya presentase kepemilikan institusional tidak mendorong komite audit untuk memilih publikasi sustainability report, melainkan lebih berfokus menyelesaikan temuan-temuan audit serta menelaah pengaduan dalam perusahaan dan tidak berfokus pada pengungkapan tanggung jawab sosial melalui sustainability report secara langsung.

Hipotesis kedelapan menyatakan bahwa kepemilikan institusional memoderasi pengaruh ukuran perusahaan pada sustainability report. Hasil pengujian pada penelitian ini menunjukan nilai koefisien variabel moderasi yaitu interaksi antara kepemilikan institusional dengan ukuran perusahaan sebesar 1,505 dengan tingkat signifikansi yang diperoleh sebesar 0,031 lebih kecil dari $a=0,05$ sehingga dapat disimpulkan bahwa hipotesis diterima. Kepemilikan institusional yang tinggi akan menimbulkan pengawasan yang lebih optimal karena pihak institusional adalah pihak yang memiliki kemampuan untuk mengevaluasi kinerja perusahaan (Sintyawati dan Dewi, 2018). Perusahaan besar yang memiliki lebih banyak pemegang saham institusi memiliki perhatian terhadap program sosial yang dilakukan oleh perusahaan (Majeed et al., 2015). Hasil penelitian ini sejalan dengan penelitian yang dilakukan oleh Nurleni et al. (2017), Rohmah (2015), Aliniar \& Wahyuni (2017), Majeed et al. (2015) yang mendapatkan hasil bahwa kepemilikan institusional berpengaruh positif pada sustainability report.

\section{SIMPULAN}

Berdasarkan hasil penelitian dengan analisis data yang telah dilakukan maka dapat ditarik kesimpulan bahwa dewan direksi berpengaruh positif pada sustainability report. Hal ini berarti pertemuan antar anggota direksi melalui rapat dapat mewujudkan tata kelola perusahaan yang baik. Komisaris independen 
berpengaruh positif pada sustainability report. Hal ini berarti bahwa semakin tinggi jumlah komisaris independen, maka semakin efektif pengawasan dan memastikan perusahaan telah melakukan tanggung jawab sosial yang diungkapkan melalui sustainability report. Komite audit berpengaruh positif pada sustainability report. Hal ini berarti bahwa rapat komite audit yang diadakan secara berkala dapat mendorong pengawasan yang mendalam pada proses Corporate Governance, salah satunya yaitu aktivitas tanggung jawab sosial, yang diungkapkan melalui sustainability report. Ukuran pengawasan berpenaruh negative yang berarti semakin besar perusahaan tidak menjamin perusahaan akan melakukan publikasi sustainability report yang kemudian mendapatkan legitimasi dari publik. Kepemilikan institusional mampu memoderasi pengaruh dewan direksi, komisaris independen, dan ukura perusahaan pada sustainability report, namun tidak mampu memoderasi pengaruh komite audit pada sustainability report.

Peneliti selanjutnya diharapkan agar dapat mengembangkan penelitian untuk meneliti faktor lain yang berkaitan dengan sustainability report seperti kepemilikan saham pemerintah. Diharapkan lebih banyak perusahaan menyusun sustainability report, dan agar selalu konsisten untuk mengeluarkan sustainability report. dengan adanya sustainability report hendaknya investor menilai perusahaan tidak hanya melihat pada aspek ekonomi perusahaan saja, tetapi bagaimana perusahaan tersebut peduli pada lingkungan dan sosialnya melalui sustainability report sehingga para investor dapat mengambil keputusan yang tepat sebelum berinvestasi ke perusahaan dan secara tidak langsung dapat turut andil dalam menjaga keberlanjutan sosial, ekonomi, dan lingkungan.

\section{REFERENSI}

Abdoellah, O. (2016). Pembangunan Berkelanjutan di Indonesia. PT Gramedia Pustaka Utama.

Adila, W., \& Syofyan, E. (2016). Pengaruh Corporate Governance dan Karakteristik Perusahaan Terhadap Pengungkapan Sustainability Report: Studi Empiris pada Perusahaan yang Terdaftar di BEI tahun 2010-2014. Jurnal WR, 4(2), 777-792.

Aliniar, D., \& Wahyuni, S. (2017). Pengaruh Mekanisme Good Corporate Governance (GCG) Dan Ukuran Perusahaan Terhadap Kualitas Pengungkapan Sustainability Report Pada Perusahaan Terdaftar Di Bei. Jurnal Universitas Muhammadiyah Purwekerto, 15(1), 26-41.

Awalia, E. N., Anggraini, R., \& Prihatni, R. (2015). Pengaruh Dewan Direksi, Dewan Komisaris Independen, Laverage, Dan Aktivitas Perusahaan Terhadap Pengungkapan Sustainability report. Jurnal Articel, 10(2), 124-139.

Barung, M., Simanjuntak, A. M. A., \& Hutadjulu, L. Y. (2018). Pengaruh Mekanisme Good Corporate Governance Dan Ukuran Perusahaan Terhadap Kualitas Pengungkapan Sustainability Report (Studi Empiris Pada Seluruh Perusahaan Yang Listing Di Bursa Efek Indonesia Periode 20112016). Jurnal Akuntansi \& Keuangan Daerah, 13(November), 76-89. https://doi.org/10.1017/CBO9781107415324.004

Bose, S., Saha, A., Khan, H. Z., \& Islam, S. (2017). Non-financial disclosure and market-based firm performance: The initiation of financial inclusion. Journal 
of Contemporary Accounting and Economics, 13(3), 263-281. https://doi.org/10.1016/j.jcae.2017.09.006

Dharmawan Krisna, A., \& Suhardianto, N. (2016). Faktor-Faktor yang Mempengaruhi Pengungkapan Tanggung Jawab Sosial. Jurnal Akuntansi Dan Keuangan, 18(2), 119-127. https://doi.org/10.9744/jak.18.2.119-128

Diono, H., Jatmiko, T., \& Prabowo, W. (2017). Analisis Pengaruh Mekanisme Corporate Governance, Profitalbilitas, Dan Ukuran Perusahaan Terhadap Tingkat Pengungkapan Sustainability Report. Analisis Pengaruh Mekanisme Corporate Governance, Profitalbilitas, Dan Ukuran Perusahaan Terhadap Tingkat Pengungkapan Sustainability Report, 6(3), 615-624.

Division, A., \& Group, A. S. (2018). The Effect Of Firm' S Characteristic And Corporate Governance. 2(1), 18-28.

Fatchan, I. N., \& Trisnawati, R. (2018). Pengaruh Good Corporate Governance Pada Hubungan Antara Sustainability Report Dan Nilai Perusahaan (Studi Empiris Perusahaan Go Public di Indonesia Periode 2014-2015). Riset Akuntansi Dan Keuangan Indonesia, 1(1), 25-34. https://doi.org/10.23917/reaksi.v1i1.1954

Ferri, L. M., Pedrini, M., \& Pilato, V. (2016). The management of stakeholder dialogue in different institutional contexts: an empirical study on FTSE4GOOD companies. Journal of Cleaner Production, 136, 226-236. https://doi.org/10.1016/j.jclepro.2016.01.100

Glembotskaya, G. T., Eremin, S. Y., \& Chupandina, E. E. (2020). Scientific priorities and real prospects for cost optimization in formulation development. Entrepreneurship and Sustainability Issues, 7(3), 1484-1499. https://doi.org/10.9770/jesi.2020.7.3(4)

Hani, M. (2017). Faculty of Economics Riau University ,. JOMFekom, 4(1), 843-857. https:/ / media.neliti.com/media/publications/125589-ID-analisis-dampakpemekaran-daerah-ditinja.pdf

Hasanuddin, M. Z., \& Suryani, E. (2019). The Influence of Financial Performance, Corporate Governance, and Stock Prices to the Sustainability Reporting (Study of companies that listed on Indonesia Stock Exchange in 2014 - 2017). 343(Icas), 119-123. https:// doi.org/10.2991/icas-19.2019.26

Khafid, M. (2012). Kontribusi Karakteristik Perusahaan dan Corporate Governance Terhadap Publikasi Sustainability Report. Jurnal Ekonomi Dan Keuangan, 80, 340-359.

Liana, S. (2019). Pengaruh Profitabilitas, Leverage, Ukuran Perusahaan dan Dewan Komisaris Independen terhadap Pengungkapan Sustainability Report. Jesya (Jurnal Ekonomi \& Ekonomi Syariah), 2(2), 199-208. https://doi.org/10.36778/jesya.v2i2.69

Lindawati, A. S. L., \& Puspita, M. E. (2015). Corporate Social Responsibility: Implikasi Stakeholder dan Legitimacy Gap dalam Peningkatan Kinerja Perusahaan. Jurnal Akuntansi Multiparadigma, 157-174. https://doi.org/10.18202/jamal.2015.04.6013

Madona, M. A., \& Khafid, M. (2020). Pengaruh Good Corporate Governance terhadap Pengungkapan Sustainability Report dengan Ukuran Perusahaan sebagai Pemoderasi. Jurnal Optimasi Sistem Industri, 19(1), 22. https://doi.org/10.25077/josi.v19.n1.p22-32.2020 
Mahmood, Z., Kouser, R., Ali, W., Ahmad, Z., \& Salman, T. (2018). Does corporate governance affect sustainability disclosure? A mixed methods $\begin{array}{llll}\text { study. Sustainability } & \text { (Switzerland), } & 10(1), & 1-20 .\end{array}$ https://doi.org/10.3390/su10010207

Majeed, S., Aziz, T., \& Saleem, S. (2015). The Effect of Corporate Governance Elements on Corporate Social Responsibility (CSR) Disclosure: An Empirical Evidence from Listed Companies at KSE Pakistan. International Journal of Financial Studies, 3(4), 530-556. https://doi.org/10.3390/ijfs3040530

Manurung, D. et al. (2017). Effect of Corporate Governance, Financial Performance and Environmental Performance on Corporate Social Responsibility Disclosure. Asian Journal of Finance \& Accounting, 6(1), 15-28. https://doi.org/10.5296/ajfa.v10i1.12592

Needles, B. E., Frigo, M. L., Powers, M., \& Shigaev, A. (2016). Integrated reporting and sustainability reporting: An exploratory study of high performance companies. Studies in Managerial and Financial Accounting, 31, 41-81. https:// doi.org/10.1108/S1479-351220160000031019

Noviani, K., Yuniarta, G. A., \& Wahyuni, M. A. (2017). Pengaruh Tingkat Profitabilitas, Komposisi Dewan Komisaris Independen, dan Kepemilikan Institusional terhadap Pengungkapan Corporate Social Responsibility Perusahaan Perbankan yang Terdaftar di Bursa Efek Indonesia Tahun 2014 2016. E-Journal Akuntansi, 8(2).

Nurleni, Bandang, A., \& Amiruddin, A. (2017). The Effect of Managerial and Institutional Ownership on Corporate Social Responsibility Disclosure. International Journal of Law and Management, 60(4), 979-987.

Pramiana, O., \& Anisah, N. (2018). Implementasi Corporate Social Responsibility (CSR) Dalam Perspektif Shariah Enterprise Theory. Jurnal Riset Ekonomi Dan Bisnis, 13(2), 169-182.

Ria, Aniktia; Muhammad, K. (2015). Pengaruh Mekaniseme Good Corporate Governance Dan Kinerja Keuangan Terhadap Pengungkapan Sustainability Report. Accounting Analysis Journal, 4(3), 1-10. https://doi.org/10.15294/aaj.v4i3.8303

Rohmah, D. (2015). Faktor-Faktor Yang Mempengaruhi Pengungkapan Corporate Social Responsibility Di Dalam Laporan Sustainability (Studi Empiris Pada Perusahaan yang listing di Bursa Efek Indonesia Tahun 2010-2013). 5(2), 243-262.

Ruhana, A., \& Hidayah, N. (2020). The Effect of Liquidity, Firm Size, and Corporate Governance Toward Sustainability Report Disclosures (Survey on: Indonesia Sustainability Report Award Participant). 120(Icmeb 2019), 279-284. https://doi.org/10.2991/aebmr.k.200205.048

Sinaga. (2017). The Effect of Profitability, Activity Analysis, Industrial Type and Good Corporate Governance Mechanism on The Disclosure of Sustainability Report. Accounting Analysis Journal, 6(3), 347-358. https://doi.org/10.15294/aaj.v6i3.18690

Sintyawati, Ni Luh Ary, M. R. D. S. \& Made Rusmala Dewi S (2018). Pengaruh Kepemilikan Manajerial, Kepemilikan Institusional Dan Leverage Terhadap Biaya Keagenan Pada Perusahaan Manufaktur. E-Jurnal Manajemen Unud, 7(2), 993-1020.

Sofa, F. N., \& Respati, N. W. (2020). Ukuran Perusahaan terhadap Pengungkapan 
Sustainability Report ( Studi pada Perusahaan Manufaktur yang Terdaftar di Bursa Efek Indonesia Tahun 2017 ). Jurnal Ekonomi Dan Bisnis, 13(1), 3249.

Tamrin, M., \& Maddatuang, B. (2019). Pencapaian Konsep Good Corporate Governance dalam Industri Manufaktur di Indonesia. PT Penerbit IPB Press.

Wang, M. C. (2017). The relationship between firm characteristics and the disclosure of sustainability reporting. Sustainability (Switzerland), 9(4). https://doi.org/10.3390/su9040624

Wartina, Prima Apriweni, E. (2018). Dampak Kinerja Lingkungan, Kepemilikan Institusional, Kepemilikan Publik, Leverage, Ukuran Perusahaan Dan Pertumbuhan Perusahaan Terhadap Pengungkapan Tanggungjawab Sosial. Jurnal Akuntansi, 7(1), 31-52. https://doi.org/10.46806/ja.v7i1.454

Willyanto, P., Marciano, D., \& Siswantoyo, D. (2019). The Impact of Corporate Governance on Firm's Performance with Capital Structure as an Intervening Variable. 73, 158-164. https://doi.org/10.2991/aicmar-18.2019.12

Zahir, M., Soewarno, N., \& Airlangga, U. (2020). The Effect of Firm Sizes on Firm Performance: GCG Mechanism and CSR Disclosure as Intervening Variables in an Indonesian Study. International Journal of Innovation, Creativity and Change, 13(4), 1418-1435. https://doi.org/10.17051/ilkonline.2020.04.160

Burns Weston, S. (2015). International Journal of Ethics. Kant-Studien, 5(1-3). https://doi.org/10.1515/kant-1901-0143 